Published in: Wenceslao J. Gonzalez (ed.), The Limits of Science: an Analysis from

"Barriers" to "Confines", Leiden/Boston (Brill/Rodopi) 2016, 94-111 (preprint version)

\title{
Ethical Limits of Science, Especially Economics
}

Gereon Wolters, University of Konstanz, Germany

\begin{abstract}
I give (I) conceptual clarifications relevant for our argumentation: facts versus norms/values, ethical pluralism versus ethical relativism, moral norms versus juridical norms. It is shown that ethical norms are justified using the principle of universalization: ethical arguments may use only principles to which supposedly everybody could give assent. I then (II) deal with ethical limits to the freedom of science imposed from outside, i.e. legislation (e.g. restrictions on experiments on animals or humans), or (III) imposed from inside, i.e. science itself (e.g. research moratoria, measures to prevent corruption). I then (IV) turn to economics, showing that the leading neoclassical economical theory is among the causes for the enduring financial and economic crisis. I defend three theses: (1) Neoclassical economics has unethically sold itself as safely explaining and predicting as physics. (2) The models of neoclassical economy are based on value-laden ideological beliefs about free markets and economical agents that are sold as value-free science. (3) Neoclassical experimentation that involves whole countries and societies (like the completely failed "Chile experiment") is immoral.
\end{abstract}

\section{Conceptual Introduction}

In times of Latin as lingua franca of science and philosophy, our topic today would have been limites scientiae ethici. Those of you who have had the good luck to have learned Latin at school might immediately ask: is the genitive scientiae a genetivus subjectivus or objectivus? Or, put differently, does the title ask for ethical limits that are internal to the process of science, i.e. ethical limits of science, or, are 
we inquiring, whether ethical limits should be imposed on science from outside, i.e. ethical limits to science. The short answer is: both. We will see that, on the one hand, the process itself of conducting science often raises ethical questions, and that the application of results of science, on the other, may pose ethical problems. The typical addressee of the internal ethical problems is the scientist him- or herself, while the typical addressee of the consequential problems is the society or the lawgiving bodies, respectively. On the basis of this distinction the title of the paper would better read as: "Ethical Limits of and to Science".

Ethics seems to be a topic philosophers, and sometimes also theologians, deal with in a professional way. We might ask, why doesn't one leave to the scientists and doctors themselves the reasoned answer to ethical questions that arise in their respective disciplines? The answer that scientists and physicians often find difficult to accept is that scientific or medical competence is categorically different from ethical competence. Scientific competence relates to the facts of the world and delivers descriptive results, while ethical competence relates to norms and values and delivers evaluative and normative results. In short, science tells us what there is, while ethics tells us, what we should do, or which things we should value. This doesn't exclude that a scientist or doctor may give valuable ethical guidelines. But in doing this they do not make use of their scientific or therapeutic but rather of their philosophical competence. Such competence, however, often is badly missing. The degree of confidence of scientists and doctors in their ethical arguments is often negatively proportional to their quality. This we find, of course, also in philosophy and elsewhere, and not only when it comes to the ethics of science.

In standard philosophical parlance, there is an important difference between "ethics" and "morals". "Morals" relate to actually existing rules or norms of conduct of persons or groups. It does not matter whether those rules are "good" or "bad". Thus, one speaks, for example, of the morals of the Mafia, or of the investment banking elite of bank $X$, and at the same time of the morals of the Catholic Church, or rural Lutheran communities in Northern Finland. What these examples have in common and what distinguishes them from "ethics" is their lack of universal justification. Sure, the moral rules of the Catholic Church are intended to further the common good, 
different from those of the Mafia or the banks. But their justification has to finally rely on the existence of God and on the authoritative interpretation of His word by the Church, both of which cannot claim universal assent.

It is the philosophical sub-discipline ethics that attempts the justification of moral norms in a universalized form. "Universalization" means: taking recourse to principles and arguments to which supposedly everybody could give assent, provided that one lives with the intention to morally respect other people. Kant has called this intention "the good will" (der gute Wille). There is a large variety of attempts to systematize ethics: Kantian ethics is based on the "categorical imperative". One of its formulations is: "act only according to that maxim whereby you can at the same time will that it should become a universal law without contradiction". ${ }^{1}$ So called consequential ethics concentrate on the overall consequences of our actions and are based on some principle of utilitarianism, e.g. Jeremy Bentham's classical definition:

"By the principle of utility is meant that principle which approves or disapproves of every action whatsoever according to the tendency it appears to have to augment or diminish the happiness of the party whose interest is in question: or, what is the same thing in other words to promote or to oppose that happiness.". 2

These first two really universalizing approaches to ethics have been refined and reformulated in the course of the more than 200 years of their existence. They are at the same time the most explicit examples of ethical universalization. Although others, less explicit ones, exist, like the recourse to Aristotelian virtue ethics, and all sorts of mixed systems, we could, nonetheless, say: ethical norms are universalistically justified moral norms.

As to ethical norms there is a striking similarity to the descriptive realm, which is characteristic of science. As is universally accepted these days, all scientific statements are as a matter of principle hypothetical, even the optimally justified and

\footnotetext{
${ }^{1}$ KANT, I., Grounding for the Metaphysics of Morals [1785], English translation by J. W. ELLINGTON, Hackett, Cambridge Mass., 3rd edition 1993, p. 30.

2 Bentham, J., An Introduction to the Principles of Morals and Legislation [1789], Dover Publications, Mineola N.Y., 2007, p. 1.
} 
reliable ones. There is, on principle, no absolute or infallible knowledge in the realm of the factual, even if we are convinced that many scientific statements, laws of nature etc. hold firmly without any prospect of ever changing. What applies to the descriptive realm applies also to the normative. Ethical justification is based on principles, which we cannot "prove" in a definite sense - as little as we can "prove" the laws of nature. This is already clear from the fact that there exist various such principles, whose application may lead to diverging moral norms. Apart from that, the application of ethical principles and moral norms is not an algorithmic procedure that leads to the same results with everybody. Rather, it rests on judgment, and judging has to take into account both the principles and the circumstances of their application. The result is what one might call moral pluralism. Moral pluralism is the form of morals in secular democratic states, where no institution can claim to be in the possession of absolute truths, be it scientific truths, be it moral truths.

Moral pluralism, however, does not mean moral relativism, because - despite their differences - all moral principles have one thing in common: their ratio essendi is the insight that other beings have moral rights towards us. Every universal ethical conception can be regarded as an attempt at developing the norms, which are included in the moral respect that we owe to other beings. This common ground in my view unites different ethical approaches more than their differences separate them.

Another distinction is of great importance in our context: the difference between ethics and law. ${ }^{3}$ Sure, both fields overlap: There are many laws that have an ethical foundation. Think, for example, of those sections of the penal code that forbid murder, fraud, pedophiliac actions and the like. Such sections are the forensic form of moral norms plus the threat of punishment for their violation. But there are moral norms as the imperative not to lie or imperatives in the wide field of partnership that - in general - are not at the same time legal norms. Another difference between moral norms and legal norms relates to conviction. Legal norms require simply a

\footnotetext{
${ }^{3}$ Much that relates to this topic is drawn from WOLTERS, G., „Einschränkungen der Forschungsfreiheit aus ethischen Gründen?", in: HOLZHEY H., JAUCH, U. P. y WüRGLER, H. (eds.), Forschungsfreiheit. Ein ethisches und politisches Problem der modernen Wissenschaft, vdf, Zürich, 1991, pp.199214.
} 
certain behavior. It is irrelevant, whether one takes a legal norm to be reasonable or nonsense as long as one behaves according to that norm. Take e.g. speed limits. It does not matter whether you deem speed limits as severe restriction of your freedom, as long as you keep within the speed limit. It is hardly imaginable, however, that somebody speaks the truth even to his/her disadvantage, but at the same time reckons the moral norm "you shall no lie!" to be mistaken.

Most important in the context of morals and law is the question, which moral norms should be protected by law. As to be expected, there exist different answers to this question. I very much support the enlightenment conception, which includes that religion is a private affair, and that, accordingly, religion and state should be kept separate from each other. ${ }^{4}$ This includes that norms based on religious belief do not have any privilege in the political discussion about legal sanctions of moral norms. Furthermore, I support the liberal conception that the democratic state should interfere with the private concerns of citizens as little as possible and as much as necessary. This leads to the answer that moral norms need legal sanctioning only if they express a common good whose implementation is vital for the functioning of society.

\section{Moral Limits Imposed on Science}

After this long conceptual overture we have, finally, properly arrived at our topic. Let us first have a look at moral limits that are imposed on science from outside, i.e. by law. Putting morally justified legal limits to science means, first of all, restricting academic freedom. Probably in all European countries academic freedom is guaranteed either by law or by the constitution. The German Constitution of 1949 (Grundgesetz) in its first part on the fundamental rights of the citizens succinctly states:

\footnotetext{
${ }^{4}$ In WOLTERS, G., „Aufklärung und Religion - damals und heute“, in BUSER P., DeBRU C. y MeYer P. (eds.), Les Lumieres: hier, aujourd 'hui, demain - Science e societè. [...] Colloque interacadémique franco-allemand [...], Hermann Ėditeurs, Paris, 2013, pp. 219-238 I have given an analysis of the relationship between religion and enlightenment. Different from France in countries like Germany the Churches hold still remarkable privileges. In Germany they include the restriction of the freedom of research and teaching at state universities (see section IV of that paper).
} 
"Art and science, research and teaching are free. The freedom of teaching does not absolve from the allegiance to the constitution." ${ }^{5}$

Similarly the Spanish Constitution of 1978 states in article 20.1c of its first section "De los derechos fundamentales y de las libertades públicas":

"Se reconocen y protegen los derechos: [...] a la libertad de cátedra."6

The status of academic freedom as a fundamental right implies that possible restrictions of this right need convincing justifications. Restrictions of academic freedom exist in every European country. Although I can speak here only about the German case, I am pretty sure that things in Spain are not entirely different. Here a few examples: there are restrictions of research in order to protect animals. To the best of my knowledge there are laws, based on moral considerations, in every European country that restrict animal experimentation. Much stricter laws hold for experiments on humans, which, in addition, are regulated by international declarations. Such declarations elaborate and adjust the first such declaration of Helsinki of 1964 to new circumstances.

Another example of moral restrictions of research relates to genetic cloning of humans. There are people who are so sure of themselves that they would like to genetically multiply. As we know, the technique of genetic cloning works in the animal kingdom. Some of you might remember the first cloned mammal: Dolly, the domestic sheep that was born as a clone of another female sheep. Why not clone humans? Why not have a second and even more editions of Silvio Berlusconi, Lady Gaga or Lionel Messi? Sure, we know from epigenetics and from the importance of culture in human development that such clones would not be as identical with the original as the latter might want. But in any case, some spectacular similarity would come about. To the best of my knowledge there does not yet exist a human clone. The legal situation in Europe is somewhat confusing. In Spain cloning is prohibited by the

\footnotetext{
${ }^{5}$ Basic LaW OF THE Federal Republic of GeRmany (1949), article. 5, section 3, available at: http://en.wikisource.org/wiki/Basic Law for the Federal Republic of Germany.
}

${ }^{6}$ CONSITUCIÓN ESPAÑOLA DE 1978, available at: http://es.wikisource.org/wiki/Constituci\%C3\%B3n espa\%C3\%B1ola de 1978 
European Convention on Human Rights and Biomedicine that has been ratified by Spain, while most other European countries have not joined so far. ${ }^{7}$

One can adduce here various moral reasons for prohibiting reproductive cloning of humans. I would like to mention only two: First of all, one would need experiments in order to establish procedures. As everybody knows, experiments can go wrong and deliver undesired results. How about a cloned baby that is born with a severe handicap? Furthermore, as with Dolly, there is the possibility that also a human clone, which is seemingly born healthy, develops ailments over time that are related to his or her being a clone. Describing such cases gives already an answer to our question about restricting academic freedom in this area: Cloning is morally excluded by simple moral principles.

The restrictions I have talked about so far, i.e. restrictions concerning experiments on animals or humans are restrictions that directly relate to the process of research. Many more moral problems arise, however, when it comes to the application of research. In Germany for many years there has been a vivid public discussion about preimplantation genetic diagnosis (PGD), which was forbidden until recently by the Embryo Protection Law of 1990, while in most other European countries PGD was practiced without legal problems. What is at issue? -

PGD is a diagnostic procedure that allows genetic screening of an embryo generated by in vitro-fertilization, before it is implanted. It is used in cases in which there exists a high risk that a baby will be born with a severe hereditary disease. The ethical questions that arise in the context of PGD are basically the same as in the case of abortion. Minor issues concern the question of surplus embryos or the valuation of handicapped life.

Note that any restriction in the case of PGD does not relate to scientific research but rather to its application. Similar questions arise in other fields. Take atomic research as it is applied by the atomic industry in order to construct atomic power plants. Again, atomic research itself is "innocuous", its application is not. To mention just one point: atomic waste. Plutonium-239 that is generated in reactors has

\footnotetext{
7 This results at least from the Wikipedia article „Human Cloning“ (seen March 2014).
} 
a half life of 24,000 years. Note that we can identify the first Egyptian cultures some 6,000 years ago. Could they properly communicate with us, as we now should be able to communicate with cultures several times farther ahead of us, and tell them how they have to treat nuclear waste? I doubt this very much. Apart from this there is the moral problem of future generations that will live much closer to us: they might have to pay the price for our way of life.

\section{Moral Limits Set by Scientists Themselves}

In this section I would like to talk about moral limits that are imposed on science not from outside but, rather, set by researchers themselves. This may occur on the individual as well as on the institutional level. Somebody might opt out from a certain type weapon related research, e.g. chemical weapons, because he/she objects to the use of such weapons for moral reasons. Others might leave military research altogether because for them wars in general are morally unjustified. There are possibly more such individual pacifist options than we might hear of in the media.

An interesting historical example is the German Uranprojekt, which from 1939 on tried to lay the scientific foundations for building an atomic reactor and a bomb. Particularly physicists Werner Heisenberg and Otto Hahn seem to have had great hesitations to build the bomb for the Nazi government. This results from intercepted conversations of the German scientists in Farm Hall (England), where they had been detained after the war by the British secret service. ${ }^{8}$ Particularly Hahn, who in 1938 had detected nuclear fission in 1938, felt personally co-responsible for the death of more than 90,000 people in Hiroshima, where the first (American) atomic bomb was dropped.

A more recent example of a research moratorium on an institutional level are the guidelines that were worked out at a conference on recombinant DNA in Asilomar (California) in 1975. This had to do with the potential danger of creating deadly monsters by genetically modifying existing ones. The guidelines forbade, in fact,

${ }^{8}$ Cf. Hoffmann, D. (ed.), Operation Epsilon. Die Farm-Hall-Protokolle oder die Angst der Alliierten vor der deutschen Atombombe, Rowohlt, Berlin, 1993. 
certain types of potentially dangerous experiments. The Asilomar conference and its guidelines turned out to be a milestone in the development of interaction between biological science and society. Scientists became more and more aware that they owe responsibility for their work to the society that finances it. Financing leads us to another problem in the context of ethical limits of research.

I would like to mention here only one point that is related to the problem that much research is not financed by the state or public institutions but by private companies. Private companies do not act for philanthropic reasons. They would like to see a quick return for the money they invest. One could say, of course, there is no problem: science delivers objective results. Therefore, it is of no importance who finances research. This is, unfortunately, not so. Objectivity is, in fact, one of the ideals of science. It is an ideal, though, that is often realized only in a rather approximate way. ${ }^{9}$ There are several epistemic parameters of research projects, where values und judgments of the researchers enter, and with them, possibly the interests of the sponsors The researchers are in many cases certainly not aware of this influence, whose existence has been proved in many cases. In a paper of 1986, Richard A. Davidson has studied 107 controlled clinical trials, in which a traditional drug therapy and a therapy with new drugs were compared. ${ }^{10}$ The 107 studies were classified in two ways. First, whether they favored the new drugs or the traditional drugs, and second, whether the trials were financially supported by a pharmaceutical firm or by public money. The result:

"The study has demonstrated a statistically significant association between source of funding (pharmaceutical firm versus general support) and outcome of the published clinical trials."11

\footnotetext{
${ }^{9} \mathrm{Cf}$. Introduction and many articles in MACHAMER, P., Wolters, G. (eds.), Science, Values, and Objectivity, University of Pittsburgh Press y Universitätsverlag, Pittsburgh and Konstanz, 2004..

10 DAVIDSON, R. A., „Source of Funding and Outcome of Clinical Trials,“ Journal of General Internal Medicine, v. 12.3, (1986), pp. 155-158. - Cf. in the context of funding also: BRowN James Robert (2008), "The Community of Science," in CARRIER, M., HowARD, D. y KouRAnY, J. (eds.), The Challenge of the Social and the Pressure of the Practice: Science and Values Revisited, University of Pittsburgh Press, Pittsburgh, 2008, pp. 189-216.

11 Davidson, R. A., „Source of Funding”, p. $156 f$.
} 
Although this study refrains from establishing a causal connection, everything suggests that the interests of the sponsors, perhaps without the conscious intention of the researchers, somehow diffused into the result of research.

There are more recent examples that seem to be less innocent. I rather think that they point into the direction of corruption and/or ideology. In this context Naomi Oreskes' and Eric Conway's book Merchants of Doubt is of utmost importance. ${ }^{12}$ Here is a quote from the website of the book:

"The U.S. scientific community has long led the world in research on public health, environmental science, and other issues affecting the quality of life. Our scientists have produced landmark studies on the dangers of DDT, tobacco smoke, acid rain, and global warming. But at the same time, a small yet potent subset of this community leads the world in vehement denial of these dangers. [...] Naomi Oreskes and Erik Conway explain how a loosely-knit group of high-level scientists, with extensive political connections, ran effective campaigns to mislead the public and deny wellestablished scientific knowledge over four decades. In seven compelling chapters addressing tobacco, acid rain, the ozone hole, global warming, and DDT, Oreskes and Conway roll back the rug on this dark corner of the American scientific community, showing how the ideology of free market fundamentalism, aided by a too-compliant media, has skewed public understanding of some of the most pressing issues of our era."

In my view there is no question that those scientists, whom Oreskes and Conway address, and many others they did not talk about, have severely violated the ethics of scientific research. There are, indeed, moral limits scientists ought to put themselves, in order to preserve both the ideal of scientific objectivity and the wellbeing of their society and of the whole world.

The expression "free market fundamentalism" in the above quote brings me to the last section of the paper.

12 ORESkes N., ConwaY, E., Merchants of Doubt: How a Handful of Scientists Obscured the Truth on Issues from Tobacco Smoke to Global Warming, Bloomsbury, New York, Berlin y London, 2010. 


\section{Ethical Limits of Science - Largely Ignored by Economists}

Commencing in 2007, Western countries have been experiencing an enormous economic crisis, Spain being one of those hit hardest. The crisis began as a crisis of financial markets triggered by the U.S. real estate bubble, the bankruptcy of the Lehman Bank, the almost meltdown of the AIG insurance giant, and similar disasters. ${ }^{13}$ Quickly, real economy was affected with devastating social consequences.

There exists a "Financial Crisis Inquiry Report" of 662 pages that the "National Commission on the Causes of the Financial and Economic Crisis in the United States"14 presented to the US government in January 2011. Its "Conclusions" about the causes of the crisis, which has been judged as "avoidable", are as follows:

"[...] widespread failure in financial regulation and supervision proved devastating to the stability of the nation's financial markets. [...] dramatic failures of corporate governance and risk management at many systematically important financial institutions were a key cause of this crisis. [...] a combination of excessive borrowing, risky investments, and lack of transparency put the financial system on a collision course with crisis. [...] We conclude the government was ill prepared for the crisis, and its inconsistent response added to the uncertainty and panic in the financial markets. [...] there was a systematic breakdown in accountability and ethics. [...] collapsing mortgage-lending standards and mortgage securitization pipeline lit and spread the flame of contagion and crisis. [...] over-the-counter derivatives contributed significantly to this crisis. [...] the failures of credit rating agencies were essential cogs in the wheel of financial destruction."

\footnotetext{
${ }^{13}$ A fascinating analysis gives STIGLITZ, J.E., Freefall. Free Markets and the Sinking of the Global Economy, W. W. Norton, New York, 2010. - Stiglitz is one of the winners of the Nobel Prize in economics in 2001, and at the same time one of the most thorough critics of the ruling neoclassical paradigm (see below).

14 The "Conclusions" as well as the entire report are available at: fcic.law.stanford.edu/report/conclusions.
} 
The "Conclusions" conclude: "There is still much to learn, much to investigate, and much to fix. This is our collective responsibility. It falls to us to make different choices if we want different results." ${ }^{15}$

What is fascinating about this report is that nobody in the US government seems to be interested in a possible scientific background of the glamorous failure of economic policy, i.e. a possible background in mainstream economic theory, otherwise called "neoclassical economics". ${ }^{16}$

There are, however, highly respected economists, who see things differently. Joseph E. Stiglitz writes:

"As we peel back the layers of >what went wrong $<$, we cannot escape looking at the economics profession. Of course, not all economists joined in the jubilation of free market economics; not all were disciples of Milton Friedman. A surprisingly large fraction, though, leaned in that direction. Not only was their advice flawed; they failed in their basis tasks of prediction and forecasting. [...] It was not an accident that those who advocated the rules that led to the calamity were so blinded by their faith in free markets that they couldn't see the problems it was creating. Economics had moved - more than economists would like to think - from

\footnotetext{
${ }^{15}$ Although the word "fraud" occurs in the report "no fewer than 157 times", interestingly, not one high level executive has been prosecuted so far. Cf. RAKOFF, J. S., "The Financial Crisis: Why have no High-Level Executives Been Prosecuted?", The New York Review of Books, v. 61, n. 1, 2014. - The author, a United States District Judge for the Southern District of New York - Wall Street is situated there - gives fascinating answers to the title question. Among them is a juridical parallel for the political-economic "too big to fail": too big to jail. - The situation in Europe is certainly not very different.

${ }^{16}$ In this scientific context I avoid the word "neoliberalism" that has become a poorly defined "academic catchphrase" and a political combat term. On the history of "neoliberalism" cf. BOAS, T. C, GANS-MORSE, J., "Neoliberalism: From New Liberal Philosophy to Anti-Liberal Slogan," Studies in Comparative International Development, v. 44, (2009), pp. 137-161. - There is a vast and polemical anti-neoliberalism literature in all major languages. Particularly interesting is in my view MIROWSKI, P., PLEHWE, D. (eds.), The Road from Mount Pelerin: The Making of the Neoliberal Thought Collective, Harvard University Press, Cambridge Mass., 2009. Various contributions to the book show remarkable differences in "liberal" approaches to economic theory, before the "Chicago School" (Milton Friedman, and others) succeeded to establish a sort of "imperialistic" paradigm that more and more has determined mainstream economics in the rest of the world (especially Ch. 4, pp. 139-178). - Very precious insights in the thinking and acting of leading American economists, including deans of prestigious Business Schools, who often got the bulk of their income from well paid consulting and even regulating jobs, gives the documentary film FERGUSON, C., Inside Job, SONY Pictures 2010. I would like to highly recommend this movie.
} 
being a scientific discipline into becoming free market capitalism's biggest cheerleader [my emphasis]."17

Such a move from scientific theory to political cheerleader, unsurprisingly, has ethical implications as to how responsibly conduct economical theory. I would like to argue for three interconnected theses:

Thesis 1: The attempt of mainstream neoclassical economics to model itself exclusively after physics is misguided and has failed. It is, therefore, unethical to sell economical theory to the public as safely explaining and predicting.

Thesis 2: The failure of neoclassical economics rests largely on confounding abstract mathematical models with reality. Those models are based on ideological beliefs about free markets and on the conception of the economic agents as rational maximizers of their own utility (Homo oeconomicus). The connected ethical failure is the lack of reflecting the value implications of one's own approach that is sold as value-free science.

Thesis 3: Neoclassical experimentation that involves whole countries and societies is immoral.

Ad thesis 1: Neoclassical economics is something like the common background of almost everybody who at present works as an economist with Western governments, banks, firms etc. What physics, chemistry and materials science is for engineers, neoclassical economics is for business people, regulators and business related governments, and has led economists to regard their discipline as a sort of social physics. Correspondingly, critics of this approach often speak of "physics envy". Physics envy, generally, stands for the desire of mainstream social science, including above all economics, to become a science like physics: fully mathematized and reliable like mechanics, electromagnetism or quantum theory. This desire might be fueled in Anglo-Saxon countries by the linguistic peculiarity that "science" normally only relates to what elsewhere is usually called "natural science". This seems to have led to a sort of inferiority complex among economists and other social "scientists",

17 StIGLITZ, J.E., Freefall. Free Markets and the Sinking of the Global Economy, W. W. Norton, New York, 2010, p. 238. 
which they tried to overcome above all by mathematizing their disciplines. Economics has been certainly most successful in approaching this ideal. However, not only mathematics is required in order to become a true "science". What one needs, furthermore, according to aspiring real social scientists, is the hypothetical deductive method. The hypothetical deductive method is typical of natural science, but certainly not the only respectable method in town. It includes first of all constructing theoretical models, then giving testable hypotheses derived from such models, and, finally, empirical tests of the hypotheses against the reality of the social world.

I am certainly not criticizing the attempt of economics to model itself after physics, as long as two important restrictions are kept on record. Firstly, this methodological move is not necessary, although the social sciences, particularly in Anglophone countries, have almost completely adopted such modeling as the only respectable way of conducting functioning social science. Modeling economics after physics neglects, among other things, the fact that social sciences have successfully worked with models that were never tested empirically. ${ }^{18}$ Furthermore, social sciences have even effectively worked without models, e.g. with analytical narratives. Secondly, there is, moreover, a remarkable discrepancy between pretensions and reality. It has always been the aim of physics, and is, in fact, included in the hypothetical deductive model, to deliver "precise explanations and successful predictions". ${ }^{19}$ To his great surprise, philosopher Donald Gillies, when checking the textbooks of four famous Nobel Prize winning neoclassical economists (Samuelson, Arrow, Debreu, Prescott), found that they achieved neither. This led Gillies to the

"conjecture that the use of mathematics in mainstream (or neoclassical) economics has not produced any precise explanations or successful predictions. This [...] is the main difference between neoclassical

\footnotetext{
${ }^{18}$ Cf. Clark, K. A., D. M. Primo, "Overcoming 'Physics Envy': How Scientific are the Social Sciences?", New York Times March 30, 2102, available at: http://www.nytimes.com/2012/04/01/opinion/sunday/the-social-sciences-physics-envy.html.

19 GILLIES, D., "The Use of Mathematics in Physics and Economics: A Comparison," in DIEKS D. et al. (eds.), Probabilities Laws, and Structures, Springer, Dordrecht, 2012, pp. 351-362, especially p. 355.
} 
economics and physics, where both precise explanations and successful predictions have often been obtained by the use of mathematics." 20

This seems to me a rather sobering result for pretensions to model economics after physics. It points to an overassessment of the mathematical structure and predictive power of economics. It might well be that the initial and boundary conditions of economical models and the changes over time of the latter are so complex that they cannot be effectively modeled to the desired degree, at least for the time being. It might well be that economics is more like meteorology, or "like medicine" as economist Dennis Snower recently put it in an interview. ${ }^{21}$ - Similarly, Jean-Claude Trichet, president of the European Central Bank (ECB) from 2003 to 2011 , who had to deal in the front rank with the disastrous consequences of the crisis, summarizes:

"In the crisis, finally, the available economic and financial models, above all the dynamical stochastic models of general equilibrium, were largely not working." 22

Failure in explaining and predicting is not special to economics. Rather, failure is part of the normal course of science. Special to economics is, however, a possible ethical dimension of that failure. It seems obvious that many economists failed to honestly convey to their students, to politicians, and to the public the limited explanatory and predictive scope of their models, compared to those of physics. They should have known better.

There are remarkable exceptions, though, e.g. the Israeli economist Ariel Rubinstein. In the introduction to lecture notes, he tells his students:

20 Gillies, D, „The Use“, p. 362.

${ }^{21}$ SNOWER, D., „Wir Ökonomen sind Ärzte [we economists are like doctors]“, Frankfurter Allgemeine Sonntagszeitung, January 19, 2014. - Snower ist he director of the „Institut für Weltwirtschaft“ at Kiel, Germany and gave the interview on the occasion of the centenary celebration of the institute.

22 "Enfin, dans la crise, les modèles économiques et financiers disponibles - en particulier les modèles dynamiques stochstiques d'équilibre général - se sont avérés largement inopérants." ( TRICHET, J.-C., „Aujourd'hui: la théorie face à la crise“, in BUSER, P., DEBRU, C. y MEYER, P. (eds.), Les Lumières: hier aujourd'hui, demain. Science et societè - Die Aufklärung: gestern, heute, morgen. Wissenschaft und Gesellschaft. Colloque interacadémique franco-allemand 7 et 8 février 2013, à l'occasion du cinquantième anniversaire du Traité de l'Élysée, Hermann, Paris, 2013, pp. 249-265, esp. p 251). 
"I do not view economic models as an attempt to describe the world or to provide tools for predicting the future. I object to looking for an ultimate truth in economic theory, and I do not expect it to be the foundation for any policy recommendation. Nothing is >holy< in economic theory and everything is the creation of people like yourself. [...] The word $>$ model< sounds more scientific than $>$ fable $<$ or $>$ fairy tale $<$, but I don't see much difference between them. [...]. The fable is an imaginary situation that is somewhere between fantasy and reality. Any fable can be dismissed as being unrealistic or simplistic, but this is also the fable's advantage. [...] a good model in economic theory, like a good fable, identifies a number of themes and elucidates them." 23

Whatever the exact methodological value of the comparison fairy tales/models may be, it seems to me important that students of economics be unequivocally informed that they are not studying physics.

Ad thesis 2) To this failure I would like to add another one: confounding abstract models with social reality, and at the same time not reflecting the value implications at the basis of those models. First of all, neoclassical economic models do not deal with real human beings. Their agent is the Homo oeconomicus, a creation of economists. ${ }^{24} \mathrm{He}$ is understood as a rational agent that acts exclusively in order to maximize his own utility. In this context human beings are interesting only as

"consumers and firms. We assume that consumers seek to maximize utility and that firms seek to maximize economic profit, which is the difference between total revenue and total cost."25

\footnotetext{
23 Rubinstein, A., Lecture Notes in Microeconomic Theory: The Economic Agent, Princeton University Press, Princeton and London, 2012 (2nd edition), p. IX, X.

${ }^{24}$ On the concept of Homo oeconomicus cf. the encompassing analysis of KIRCHGÄSSNER, G., Homo Oeconomicus:The Economic Model of Behaviour and Its Applications in Economic and Other Social Sciences, Springer, New York, 2008. - Kirchgässner emphasizes the distinction between the methodological value of the Homo oeconomicus model, and the metaphysical assumption that people, in fact, act exclusively out of self-interest.

25 Rittenberg, L., Tregarthen, T., Principles of Microeconomics, Webversion 2010, Ch. 6, p. 2 , available at: http://www.web-books.com/eLibrary/NC/B0/B63/TOC.html.
} 
The most important instruments of homo oeconomicus in maximizing his utility are rational choice theory and game theory. Secondly, the most important boundary condition of the neoclassical approach is perhaps the so called Efficient Market Hypothesis (EMH), which states that agents on (financial) markets act completely rational on the basis of equal information. This is said to lead to a stable market equilibrium. Other boundary conditions include non-intervention from government and non regulation of markets with the exception of the regulation of money supply by the central banks. These boundary conditions are sometimes polemically called "market fundamentalism". This is the world, where Homo oeconomicus has come to life.

To be sure, using the model of Homo oeconomicus in the social sciences can create great insights, as long as one is clear about the fact that it is a methodological instrument of research and does not describe social reality in an encompassing and reliable way. Exactly this distinction between model and reality has come out of sight among many economists, ${ }^{26}$ and Homo oeconomicus seems to have become reality in stock exchanges, banks, investment firms, and so on. But there is no doubt: "Homo oeconomicus is a sociopath", as the Cornell jurist Lynn A. Stout has succinctly put it. ${ }^{27}$ In addition, Joseph Stiglitz ironically observes: "One interesting aspect of economics is that the model [of Homo oeconomicus] provides a better description of economists than it does of others, and the longer students study economics, the more like the model they become." 28

Bringing the Homo oeconomicus alive means selling abstract models as social reality. In other words, many mainstream neoclassical economists do not ask any more how humans are really wired. Rather, they claim that humans are wired just as their models assume, i.e. humans are beings that are constantly and permanently maximizing their own utility.

${ }^{26}$ Think of Jean-Claude Trichet's quote above. Trichet devotes to "L'hypothèse des marchés efficient" a particularly trenchant analysis. See TRICHET, J.-C., „Aujourd'hui: la théorie face à la crise, pp. 256258.

27 STOUT, L.A., „Taking Conscience Seriously“, in Moral Markets: The Critical Role of Values in the Economy, Princeton University Press, Princeton, 2008, pp. 157-172, p. 159

${ }^{28}$ STIGLITZ, J.E., Freefall, p. 249. - Stiglitz' remark is based on a study about attitudes of students of economy. 
This is not without importance for the ethics of research. Selling the Homo ooeconomicus in his market environment as real is not only a scientific but also an ethical failure. Allegedly value-free science is imbued with political values, basically the political market fundamentalism, preached with missionary zeal of American republicans and libertarians, particularly of the Reagan era. It soon made its way to Margaret Thatcher's Great Britain and, slightly attenuated to other countries. ${ }^{29}$ The rather enlightened American billionaire George Soros has put it this way:

"Fundamentalists believe that markets tend towards equilibrium and the common interest is best served by allowing participants to pursue their self-interest. It is an obvious misconception, because it was the intervention of the authorities that prevented financial markets from breaking down, not the markets themselves. Nevertheless, market fundamentalism emerged as the dominant ideology in the 1980s, when financial markets started to become globalized and the US started to run a current account deficit. "30

This fundamentalism has been, nonetheless, sold as science by mainstream neoclassical economy. This is not only a scientific shortcoming. Responsible scientists are also morally obliged to reflect the value presuppositions of their theories, render them explicit, and to change them, when they empirically fail or are in conflict with moral principles or principles of justice.

Ad thesis 3) My last point relates to experiments in economics. Wenceslao Gonzalez has written on ontological, methodological and epistemological aspects of various types of such experiments, focusing on the position of the German Nobel prize winner Reinhard Selten, one of the dissidents from neoclassical orthodoxy, who rejects the strong rationality assumption of that school. ${ }^{31}$ I would like to deal here with

\footnotetext{
29 I am not criticizing market economy as such, but only its fundamentalist variant.

30 Soros, G., „The Worst Market Crisis in 60 Years“, Financial Times, January 22, 2008. Available at: http://www.ft.com/int//cms/s/0/24f73610-c91e-11dc-9807-000077b07658.html\#axzz2N3WxuGO4.

31 Gonzalez, W. J., "The Role of Experiments in the Social Sciences: The Case of Economics", in KUIPERS, T. (ed.), Handbook of the Philosophy of Science - Focal Issues, Elsevier, Amsterdam, 2007, pp. 275-301.
} 
ethical problems that may result from the experimental application of neoclassical economy.

As an example I take the attempt of the "Chicago Boys" to turn upside down the economy of Chile. ${ }^{32}$ The "Chicago Boys" were a strongly connected group, whose core consisted of some twenty Chilean economists, most of whom had studied economics with Milton Friedman and others at the University of Chicago. The "Boys" travelled from Chile to Chicago from the mid fifties onward thanks to a cooperation program of Chicago University with the Universidad Católica in Santiago de Chile. This is not without irony because the Catholic Social Teaching, based on the principle of justice, is hardly reconcilable with the economic and social recipes issued by neoclassical economics.

Under Augusto Pinochet's dictatorship the time had come for the Chilean "Chicago Boys" and their Chicago mentors to replace Chile's protectionist economy by American style neoclassical economy. In 1975, Pinochet appointed four "Chicago Boys" as minister of economics, minister of finance, president of the Central Bank and president of the Office of Economic Planning, respectively. The "Great Chile experiment" could start. It included privatization of the public economic sector and of the health and pension systems. Strikes were forbidden, taxes reduced, and so on. To cut a complex story short: the "Great Chile experiment" that put neoclassical economy to test, was, finally, a failure, and resulted in a collapse of the Chilean financial market in 1982. Sixteen of 50 private financial institutions went bankrupt with the usual consequences for real economy. To suffer were above all the poor.

We have seen that there are strict regulations in medicine for experiments on humans. The same does, unfortunately, not hold for economics. Ideology laden economists can do extreme social harm to people, when they are allowed to apply their theories in grand experiments as happened in the case of Chile. Protected by a dictator of a third world country they could just go ahead as their American ideological agenda suggested. If there had been democratic control, such experiments would hardly have been possible.

\footnotetext{
32 There is an excellent article "Chicago Boys" in the German Wikipedia (seen March 2014).
} 
In this context we might reflect how much, or better, how little democratic control of the financial markets is still left to sovereign states in our days.

\section{Selected Bibliography:}

BASIC LAW OF THE FEDERAL REPUBLIC OF GERMANY (1949), available at: http://en.wikisource.org/wiki/Basic Law for the Federal Republic of Germany

BOAS, T. C, J. GANS-MORSE, "Neoliberalism: From New Liberal Philosophy to Anti-Liberal Slogan," Studies in Comparative International Development, v. 44, (2009), pp. 137-161.

Bentham, J., An Introduction to the Principles of Morals and Legislation [1789], Dover Publications, Mineola N.Y., 2007.

Brown J. R., "The Community of Science," in CARRIER, M., Howard, D. and Kourany, J. (eds.), The Challenge of the Social and the Pressure of the Practice: Science and Values Revisited, University of Pittsburgh Press, Pittsburgh, 2008, pp. 189-216.

CARrier, M., Howard, D., and Kourany, J. (eds.), The Challenge of the Social and the Pressure of the Practice: Science and Values Revisited, University of Pittsburgh Press, Pittsburgh, 2008.

Clark, K. A. and Primo, D.M., "Overcoming 'Physics Envy': How Scientific are the Social Sciences?", New York Times, March 30, 2102, available at: http://www.nytimes.com/2012/04/01/opinion/sunday/thesocial-sciences-physics-envy.html.

CONSITUCIÓN ESPAÑOLA DE 1978, available at:

http://es.wikisource.org/wiki/Constituci\%C3\%B3n espa\%C3\%B1ola de 1978.

DAvidson, R. A., "Source of Funding and Outcome of Clinical Trials,“ Journal of General Internal Medicine, v. 12.3, (1986), pp. 155-158.

Ferguson, C., Inside Job, SONY Pictures 2010 (Film).

GILLIES, D., "The Use of Mathematics in Physics and Economics: A Comparison," in DIEKS D. et al. (eds.), Probabilities Laws, and Structures, Springer, Dordrecht, 2012, pp. 351-362 (= Proceedings of the ESF Research Networking Programme The Philosophy of Science in a European Perspective, Vol. 3).

Gonzalez, W. J., "The Role of Experiments in the Social Sciences: The Case of Economics", in KUIPERS, T. (ed.), Handbook of the 
Philosophy of Science - Focal Issues, Elsevier, Amsterdam, 2007, pp. 275-301.

Hoffmann, D. (ed.), Operation Epsilon. Die Farm-Hall-Protokolle oder die Angst der Alliierten vor der deutschen Atombombe, Rowohlt, Berlin, 1993

HOLZHEY, H., JAUCH, U. P. and WüRGLER, H. (eds.), Forschungsfreiheit. Ein ethisches und politisches Problem der modernen Wissenschaft, vdf, Zürich, 1991.

KANT, I., Grounding for the Metaphysics of Morals [1785], English translation by J. W. ElLINGTON, Hackett, Cambridge Mass., 3rd edition 1993

KIRChGässner, G., Homo Oeconomicus: The Economic Model of Behaviour and Its Applications in Economic and Other Social Sciences, Springer, New York, 2008.

Machamer, P. and Wolters, G. (eds.), Science, Values, and Objectivity, University of Pittsburgh Press and Universitätsverlag, Pittsburgh and Konstanz, 2004.

MIROWSKI, P. and PLEHWE, D. (eds.), The Road from Mount Pelerin: The Making of the Neoliberal Thought Collective, Harvard University Press, Cambridge Mass., 2009.

National Commission on the CAuses of the Financial and ECONOMic CRISIS IN THE UNITED STATES, Financial Crisis Inquiry Report, Washington, 2011, available at: fcic.law.stanford.edu/report/conclusions.

ORESkEs N. and Conway, E., Merchants of Doubt: How a Handful of Scientists Obscured the Truth on Issues from Tobacco Smoke to Global Warming, Bloomsbury, New York, Berlin and London, 2010.

RAKOFF, J. S., "The Financial Crisis: Why have no High-Level Executives Been Prosecuted?", The New York Review of Books, v. 61, n. 1, 2014 (available at the NYR website).

Rittenberg, L.and Tregarthen, T., Principles of Microeconomics, Webversion 2010, available at: http://www.webbooks.com/eLibrary/NC/B0/B63/TOC.html.

Rubinstein, A., Lecture Notes in Microeconomic Theory: The Economic Agent, Princeton University Press, Princeton and London, 2012 (2nd edition)

SNOWER, D., „Wir Ökonomen sind Ärzte“, Frankfurter Allgemeine Sonntagszeitung, January 19, 2014.

Soros, G., „The Worst Market Crisis in 60 Years“, Financial Times, January 22, 2008. Available at: http://www.ft.com/int//cms/s/0/24f73610-c91e11dc-9807-000077b07658.html\#axzz2N3WxuGO4. 
StIGLITZ, J.E., Freefall. Free Markets and the Sinking of the Global Economy, W. W. Norton, New York, 2010.

Stout, L.A., „Taking Conscience Seriously“, in Moral Markets: The Critical Role of Values in the Economy, Princeton University Press, Princeton, 2008, pp. 157-172.

TRICHET, J.-P. (correct: J.-C.), „Aujourd'hui: la théorie face à la crise“, in BUSER, P., DeBRU, C. y MEYER, P. (eds.), Les Lumières: hier aujourd'hui, demain. Science et societè - Die Aufklärung: gestern, heute, morgen. Wissenschaft und Gesellschaft. Colloque interacadémique francoallemand 7 et 8 février 2013, à l'occasion du cinquantième anniversaire du Traité de l'Élysée, Hermann Éditeurs, Paris, 2013, pp. 249-265.

WOLTERS, G. (1991): „Einschränkungen der Forschungsfreiheit aus ethischen Gründen?", in HOLZHEY, H., JAUCH, U. P. and WüRGLER, H. (eds.), Forschungsfreiheit. Ein ethisches und politisches Problem der modernen Wissenschaft, vdf, Zürich, 1991, pp.199-214.

WOLTERS, G., „Aufklärung und Religion - damals und heute“, in BUSER P., DEBRU C. and MEYER P. (eds.), Les Lumieres: hier, aujourd 'hui, demain Science e societè. [...] Colloque interacadémique franco-allemand [...], Hermann Éditeurs, Paris, 2013, pp. 219-238. 